\title{
Teaching English Pronunciation to EFL Students
}

\author{
Iwan Perdana ${ }^{1}$, Lulu Dwi Meiliani ${ }^{2}$, Angga Taufan Dayu $^{3}$ \\ Islamic University Of Kalimantan \\ Ipdyfara@gmail.com
}

\begin{abstract}
The purpose of this research is to find out teaching method used by teacher in teaching pronunciation and to discover the strength and weakness of the method used in teaching pronunciation to EFL students at SMP Negeri 1 Martapura Timur. The researcher used qualitative descriptive as research design. A teacher and several students were interviewed. It was found that the teacher used Audio-lingual Method to teach pronunciation. The repetition drill as the technique was chosen. Weakness of this repetition technique made students get bored easily. It is not necessary to have sophisticated equipment to teach pronunciation. Teacher as role model for students is also effective.
\end{abstract}

Keywords: teaching pronunciation; ALM; Junior High School

\section{INTRODUCTION}

It is clear to say that teaching pronunciation has important role in current situation of English teaching and learning where communicative competence is one of the main objectives. The absence of intelligible language pronunciation will lead to the conversation breakdown. It crucial since language is always written but sometime it is also articulated. Pennington \& Rogerson-revell (2019) state that pronunciation is the heart of messaging in speech by articulating word and in its' combination with other language aspect. Therefore, 
good language pronunciation makes meaningful spoken massage transfer is possible to happen. Even though the importance of pronunciation is fundamental, it existence in teaching learning process is still unclear. According to Moedjito (2008), although pronunciation is one of the key elements of successful oral communication, unfortunately the teaching of English pronunciation is almost neglected. Only little attention is given to the teaching of English pronunciation, particularly in the context where written test is the main objective of English language teaching. Further, Harmer (2001) states the lack of high quality, suitable teaching and learning materials, and the lack of time to practice pronunciation are the major reasons that cause teachers do not pay enough attention to English pronunciation. Therefore, it can be stated that teaching pronunciation is still far from what we call "satisfactory" and still has many problems.

Several studies have been conducted to figure out the current situation of teaching pronunciation in classroom. Gilakjani and Sabouri (2019) conclude that teaching pronunciation should be integrated into classroom activities and EFL teacher should pay attention to their students' pronunciation problems. Darmayanti (2017) on her study conclude that in teaching student at senior high school teacher should choose appropriate technique while teaching pronunciation. The teachers should consider students' attributes before choosing particular technique to teach pronunciation. Bai \& Yuan (2018) investigate the belief of university teachers' on teaching pronunciation. The result show that even though teachers have positive belief about teaching pronunciation, there is discrepancies in practice.

Further, Moedjito (2016) on his study, invested teachers' and university students' perception regarding teaching pronunciation. He highlighted three points as the conclusion of his study. First, despite of its difficulties, teachers and students agree the importance of pronunciation in learning English. Second, the predominant difficulties in learning pronunciation is the absent of target language sound in students' native language sound. Third, the implementation of teaching pronunciation should consider local context demand, especially students' native language, the balance of fluency and accuracy, the segmental features (e.g., consonants, vowels, IPA-based phonetic transcription) and suprasegmental features (e.g., intonation, rhythm, word stress), and a variety of techniques of pronunciation teaching (e.g., teacher explanation in L1, minimal pairs, teacher demonstration)".

The result of aforementioned studies reveal that there are much to be explored in teaching pronunciation. The result of the study also show that different teaching context will lead to different result of the study. In the view of the significant and complexities of 
Teaching English Pronunciation to EFL Students

Iwan Perdana ${ }^{1}$, Lulu Dwi Meiliani ${ }^{2}$, Angga Taufan Dayu ${ }^{3}$

teaching pronunciation, this study seek to investigate how is teaching pronunciation in junior students level. The investigation covers teaching methodology used by the teacher, problem that the teacher has in teaching pronunciation and students' perception on teaching pronunciation.

\section{METHODOLOGY}

Qualitative approach was employed as the objective of this research was to describe natural phenomenon. The setting of this research was SMPN 1 Martapura Timur. Further, the participant of this research was one teacher of SMPN 1 Martapura Timur who teach $7^{\text {th }}$ and $8^{\text {th }}$ grade and was chosen purposively by the researcher. The data were collected through observation, interview, and documentation. Observation was administered to collect the data regarding teaching learning process in classroom. In conducting observation, the researcher made observation sheet as guidance. Further, interview was conducted to gathered personal opinion as additional data. In order to vary the data, the researcher interviewed the principal, English teacher, and students. The researcher was equipped with structured question in doing the interview. In interview session, the participants were asked not only to elaborate the practice of teaching pronunciation, but they also asked to elaborate their belief on teaching pronunciation. Lastly, documentation was conducted by the researcher to find supporting data such teacher's lesson plan for teaching pronunciation.

Guided by the research question, the data gathered were analyzed by the researcher using Data Analysis Procedure suggested by Miles and Hubberman (1994). The researcher carefully examined the gathered data and formulated important code that reflect current practice of teaching pronunciation. The researcher reduces the number of data by eliminating unnecessary data. Referring to the existing literature, the researcher formulated every existing theme of teaching pronunciation in the classroom. The researcher also identify data that show problem in teaching pronunciation and students' belief about teaching pronunciation. Following that, the researcher classified, compared and revised the emerged finding before formulate the final result of this research.

\section{FINDINGS}


In general teacher is aware of the importance of suitable teaching method in teaching pronunciation. The data from interview show that to teach pronunciation, teacher vary the teaching method, choose many teaching activities and media which can facilitate learning for students. The teacher also realizes that the main focus of teaching pronunciation in his classroom is to correct his students' mispronunciation. In addition, teacher also provide activities that make his student learn how to pronounce a particular word. As consequence, the teacher that the appropriate method for teaching pronunciation is Audio-lingual Method.

As classic method, ALM emphasize on how students master spoken and listening skills of language with less attention to the reading and writing skill. As seen in teaching learning process in classroom and shared in interview, the participant agrees that ALM give a lot of opportunities to teach his students pronunciation. With emphasize on fluency, ALM will sharpen students' pronunciation ability with less attention to others language aspects. In the interview result, the participant also stated that he has been used ALM since the very beginning of his teacher trajectory.

Furthermore, teacher belief to choose ALM as a method to teach pronunciation is related to his experience in pre-service teacher education and his experience as language learner. On the second interview, the participant asserted that the reason why he used ALM as method to teach English pronunciation is because he also taught by his teacher with the same method. The participant also believes that ALM create a good teaching atmosphere in the classroom and can make students actively engage in teaching learning process. Further, the participant also stated that when he was a language learner, he was advised by his teacher to use ALM as a method to teach English. Therefore, the participant admit that he takes the advice of his teacher because he perceive his teacher as a very experienced teacher.

In other interview, the participant added other theme to be discuss that is the effect ALM in teaching pronunciation. The participant believes that ALM bring good impact on his teaching pronunciation. The participant argues that ALM improve students' pronunciation since ALM is equipped with drill activity. Drilling system make student learn how to pronounce a word by enormous repetition. In accordance with the goals to be achieved by the teacher, this method requires determinedly and consistency of students in repeating words to make the perfect pronunciation.

The effect of ALM is also confirm by the students who taught by the teacher. The result of students' interview shows that students feel positive about the effect of ALM in teaching pronunciation. It can be said that the implementation of ALM method encourages the students to have more accurate English pronunciation. There are also students who think 
Teaching English Pronunciation to EFL Students

Iwan Perdana ${ }^{1}$, Lulu Dwi Meiliani ${ }^{2}$, Angga Taufan Dayu ${ }^{3}$

that they are more motivated to improve their own pronunciation. However, there some still some negative voice from the students regarding the role of ALM in teaching pronunciation. Many students explain that they sometime get easier to feel bored when they always taught with the same method for quite long time.

\section{The Weakness of the Method Used in Teaching Pronunciation}

The level of teaching complexity in teaching pronunciation is in line with the method convey in daily practice. When implemented to the classroom, particular method will obviously have some weakness in practice. On interview session, the participant was asked to deliver their opinion regarding the weakness of ALM when it is implemented in classroom, how participant overcome these weaknesses, to whom the weaknesses of the method have an impact, and the difficulties faced by the teacher when applying ALM method.

Discussing the weakness points of the ALM method, this refers to the level of boredom students has when it has to be implemented in classroom where the students have different level of English proficiency. For those who has good ENGLISH proficiency, repetition drill will produce boredom for them. They think they only need a maximum of 1 3 times practice and naturally these students are able to master the pronunciation.

Because they understand quickly, they get bored easily too. It was discovered that weakness of the ALM method actually had an impact on students. Students who only learn pronunciation without being taught to translate meanings of the word at the same time, will make them left behind in terms of vocabulary mastery.

Further information is about the difficulties in applying the ALM method Technically, ALM is a method that does not require high technology equipment. The ALM method does not demand a lot of media. In the interview session the teacher states that he does not find obstacles in its application in the classroom. Teacher as role models can also make the teaching and learning process run smoothly. From students' opinion, interview data show that most students agree that the weakness of ALM is when they have to pronounce a new word. Therefore, it is safe to say that ALM has little weakness when it is implemented in the classroom.

The weaknesses of pronunciation teaching for students which is repetition without meaning. This is the main problem for students. If only pronunciation is taught without knowing the meaning of the word, students will be harmed because they only know how the 
sound is produced. It is important for students to not only be satisfied when they have successfully pronounced a word correctly. It would be nice if they also find out the meaning of the word pronounced.

\section{DISCUSSION}

In general, the main aspect that need to be considered in communication is pronunciation. Communication can run smoothly when interactions between speakers and listeners can be understood by each other. This can happen if the listener is able to understand the intention of the speaker. Misunderstandings are often caused by bad pronunciation. The things above also apply when learning pronunciation in English. In teaching English pronunciation, the teacher is expected to be able to apply the right method according to students needs so that it might has positive impact such as increasing motivation and make the students play an active role in the classroom.

Following by an interview session to explore in depth information about the methods used when teaching pronunciation, and the reason the teacher chose the method. Based on interview, it can be concluded that teacher had used the Audio-lingual Method since 2013. It is believed as the most appropriate teaching method to teach pronunciation. ALM is a teaching method that emphasizes the teaching of foreign languages to listen and speak before reading and writing. The teaching and learning activities of ALM method is basically conversations and drills.

Thus, the purpose of the Audio-Lingual method is to use the target language communicatively. ALM method teaches language through dialogues that focus on habit formation of students. Larsen-Freeman (2000:45) states that students will achieve communicative competence by forming new habits in the target language and overcoming the old habits of their native language. The Audio-Lingual method considered language simply as form of behavior to be learned through the formation of correct speech habits stated by Thornbury (2000:21). The fact that ALM is effective in teaching pronunciation is in line with the result of others research. Hasanah \& Dahniar (2017) on their study also suggest that it is more effective when the ALM method is used in teaching pronunciation. The point that show ALM method is effective in teaching pronunciation is that the procedure of the method is stated to be successful in increasing students' ability to apply proper pronunciation in English. Students are accustomed to practicing speaking words that are difficult for them to say until they find that difficult words are no longer difficult to pronounce. On his study, Handoko (2016) also confirm that the pronunciation is the basic skill that should be mastered 
by learners of English. Considering the concept of Audio-Lingual Method (ALM), the drilling technique is a good technique to teach pronunciation in EFL classrooms like those in Indonesia because it emphasizes repeating through oral practice that makes foreign language students getting accustomed.

Some points that must be considered by teachers to make the pronunciation learning process effective: As a model for their students, the teachers should have good pronunciation. Otherwise they can harm their students; the students will imitate the improper pronunciation, or they can misunderstand what the teachers say. The teachers should pay more attention to each students' pronunciation; if there are any mistakes, the teachers should immediately give corrections. Teachers must realize that the abilities of each student are different, so they expected to provide more time for students who need support and guidance in pronunciation. The teachers should give instructions clearly to students to avoid them from being confused.

In Audio-lingual which involved imitation of the teacher model, pronunciation was "taught explicitly from the start" conclude by Celce-Murcia et al (1996:3). According to Brinton (2012:246) the focus of language teaching was on accuracy and thus any mistake from the teacher's model of pronunciation was considered an error. Therefore, as highlighted by writers such as Harmer (2007:24) and Brown (2009:58), it is important for teachers to gain a deeper insight into their learners' beliefs and needs. It is clearly beneficial for teachers to better understand their students' previous learning, motivation and objectives as well as attitudes towards and perceptions of language and language learning, in order to inform classroom practice.

Teachers need to become competence in recognizing, analyzing and suggesting correction for pronunciation errors. In order to do this, they need to be able to provide consistent models of the correct form and clear, accessible explanations. They should also be able to provide a suitable context for the pronunciation feature rather than treat it purely in isolation and integrate pronunciation work with other language areas when relevant. Finally, they need to be able to monitor learner's progress and give regular feedback as a means of maintaining motivation (Rogerson-Revell, 2011:244).

\section{The Weakness of the Method Used in Teaching Pronunciation}

No matter how good the student's grammar is, if the students don't know how to pronounce the word, then they will not be able to deepen their language skills. Basically, 
students who are fairly capable of mastering a lesson quickly will surely get bored immediately when taught the same teaching material continuously. Dharmayanti (2016) the results showed that, in applying drilling technique, the students felt bored and monotonous. The teacher is considered to be this technique that is effective for the students in their correct pronunciation. Based on observation, the teacher used the technique in every meeting.

Therefore, as an alternative solution, a variety of tools is needed to support the activities of the teaching and learning process. Firstly, the pronunciation is often taught by the teacher providing a model for learners to listen to and repeat but it has to understand what they are doing. Hancock (1995) introduced pronunciation teaching was presented in the form of games to reduce their dependence on their teacher as a model. There are a great variety of activities, from competitive games to problem-solving puzzles, from activities involving learners to working individually to groups and whole class activities. What the games have in common, though, are the challenges and challenges, highlighting the aspect of pronunciation.

Second type of teaching method is by using songs. For example, the use of speakers as a media for listening to songs or listening to dialogues in English conversation. Ulate (2008) concludes that the use of EFL classrooms can make learning more enjoyable and interesting. At the same time, students acquire the target language and feel comfortable in a relaxing atmosphere. This helps them lower their affective filters and become more receptive to learning. Songs, songs and learnings help improve your understanding and production of important pronunciation features. Finally, teachers should choose songs carefully, considering different levels of students' levels, age and preferences, as well as the level of difficulty of the song and its rhythm.

Teachers as role models for students practice pronunciation are also sufficient. In fact, it is not necessary to have sophisticated equipment to teach pronunciation using the ALM method. The drill was designed as an instrument for the foreign language teacher used to teach the sound and structure of the language. Drill is not reserved solely for use with the newer courses of instruction nor with the latest electronic equipment, it can be used by all teachers of language no matter which language they are teaching and no matter what other materials they are using. It can be adapted for use with the traditional textbook as well as for use with audio-lingual courses of instruction, is as useful in the classroom without language laboratory, and can be used on all levels of language instructions from courses in the elementary school groups to the most advanced courses in the college or university. 
The weakness of using ALM method to teach pronunciation for EFL students is repetition without translation meaning. This is the main concern for students. It will be harmful for students to know nothing about the translation meaning of the word they pronounce. Problem that needed to be solved is that students are not given enough information about other translation meanings of the words they pronounced. As result, students only focus to understand on one meaning. It can be caused by a lack of time for teachers to specifically teach vocabulary in class.

To make students more interested in learning pronunciation and learn new vocabulary, the teacher can overcome it by replacing the media. Ridarma (2017) concludes that viewing English subtitled videos to second grade of Man 3 Banda Aceh department can improve their ability to mastering vocabulary and pronunciation. Besides, the students were also given the questionnaire to know their obstacles towards the English subtitled videos. The students were interested and felt that this media enabled them to practice again and again in order to gain the maximal result. This media helps in understanding the pronunciation and vocabulary.

\section{CONCLUSION}

The present study give contribution the literature on how teaching pronunciation is conducted in Junior high School level. The ALM is used by the teacher as the main method in teaching pronunciation in the classroom. Teacher's personal experience plays an important role in determining ALM as method in teaching pronunciation. In its implementation in teaching pronunciation, ALM offers many advantages and shortcomings. As an advantage, ALM does not require advanced technology to be applied in the classroom. However, ALM with drilling repetition method will easily make student get bored. Students have positive belief regarding the use of ALM in teaching pronunciation and realize that they can have many advantages when taught by ALM in the classroom.

\section{REFERENCES}

Celce-Murcia, M., Brinton, D. \& J. Goodwin. (1996). Teaching Pronunciation: A 
Reference for Teachers of English to Speakers of Other Languages. Cambridge: Cambridge University Press.

Dharmayanti, Nurani. (2017). An Analysis on Teacher's Technique in Teaching

Pronunciation to Eleventh Grade of Man 3 Sragen in 2016/2017 Academic Year.

Thesis. Retrieved from http://eprints.iain-surakarta.ac.id/1283/ (Accessed on June $\left.29^{\text {th }}, 2019\right)$.

Hancock, M. (1995). Pronunciation games. Cambridge: Cambridge University Press.

Handoko, Ckristian, K., (2016). Using Drilling to Teach Pronunciation to the Seventh

Graders Ruruh Mindari. Thesis. Retrieved from http://repository.wima.ac.id

(Accessed on June 28 ${ }^{\text {th }}$, 2019).

Harmer, J. (2001). The Practice of English Language Teaching. London: Longman.

Harmer, J. (2007). The Practice of English Language Teaching. 4th edn. Harlow: Pearson Education Limited.

Hasanah, Uswatun., \& Dahniar. (2017). Teaching English pronunciation by using Audiolingual Method: A study at SMPN 2 Campalagian in Polman Regency. Thesis. Retrieved from http://journal.uin-alauddin.ac.id (Accessed on June 24 ${ }^{\text {th }}, 2019$ ).

Miles, Matthew B; Huberman, A. Michael. (1994). An Expanded Sourcebook: Qualitative Data Analysis. California: SAGE Publication, Inc.

Moedjito. (2016). The Teaching of English Pronunciation: Perceptions of Indonesian School Teachers and University Students. Retrieved from http://www.ccsenet.org/journal/index.php/elt/article/view/59572 (Accessed on June $\left.18^{\text {th }}, 2019\right)$.

Ridarma, Aulia, M., (2017). Mastering Vocabulary and Pronunciation Through Viewing English Subtitled Videos. Thesis. Retrieved from https://repository.ar-raniry.ac.id (Accessed on July $5^{\text {th }}, 2019$ ).

Rogerson-Revell, P. (2011). English phonology and pronunciation teaching. Great Britain Continuum International Publishing Group.

Thornbury, S. (2000). How to teach grammar. Harlow: Longman.

Ulate, Villalobos, N., (2008). Using Songs to Improve EFL Students' Pronunciation. Thesis. Retrieved from https://una-cr.academia.edu/NuriaVillalobosUlate (Accessed on July $3^{\text {rd }}$, 2019). 